\title{
Treating bleeding beyond correction stitches-or better, how to enhance hemostasis by topical pharmacologic support
}

\author{
Martin Czerny, MD, MBA
}

From the University Heart Center Freiburg-Bad Krozingen, Bad Krozingen, Germany.

Disclosures: Author has nothing to disclose with regard to commercial support.

Received for publication Aug 26, 2018; accepted for publication Aug 27, 2018; available ahead of print Sept 25, 2018

Address for reprints: Martin Czerny, MD, MBA, Albert Ludwigs University Freiburg-Faculty of Medicine, University Heart Center Freiburg-Bad Krozingen, Südring 15, Bad Krozingen 79189, Germany (E-mail: martin.czerny@universitaets-herzzentrum.de).

J Thorac Cardiovasc Surg 2019;157:184 $0022-5223 / \$ 36.00$

Copyright (C) 2018 Published by Elsevier Inc. on behalf of The American Association for Thoracic Surgery https://doi.org/10.1016/j.jtcvs.2018.08.058

Hypoprolenemia is the most common cause when bleeding is an issue after heart surgery, and adding additional stitches will stop the bleeding in many instances. Extensive surgical procedures needing periods of hypothermic circulatory arrest or prolonged periods of cardiopulmonary bypass or even merely clinical scenarios in which patients have to be operated on while receiving dual antiplatelet therapy or with very fragile tissue conditions, such as in chronic immunosuppression or in end-stage kidney disease, however, represent challenging conditions in which systemic pharmacologic support-cellular or plasmaticis needed to stop bleeding. 1,2

Beyond systemic pharmacologic support, topical pharmacologic support might be a very useful and sometimes even lifesaving, because there are scenarios in which additional stitches will worsen the situation rather than saving the day. Sealant is not sealant, however, and detailed knowledge of the individual properties of the now wide variety of products is needed to do the right things in the right situations. ${ }^{3}$ In addition-and this is what we have learned from experience-the effect of a topically applied sealant may outlive the acute impact and may add additional effects that are beyond the scope of the initial application, even years after the sealant's use.

This is where the value of the study in this issue of the Journal by Murdock and colleagues ${ }^{4}$ lies, teaching us that different sealants have different polymerization times, cytocompatibility properties, burst pressure strengths, elastic properties, and, finally, degradation times, and that these effects are not negligible. ${ }^{4}$ In addition, a dose effect in certain sealants is to be anticipated, although this remains subject to continuing studies.

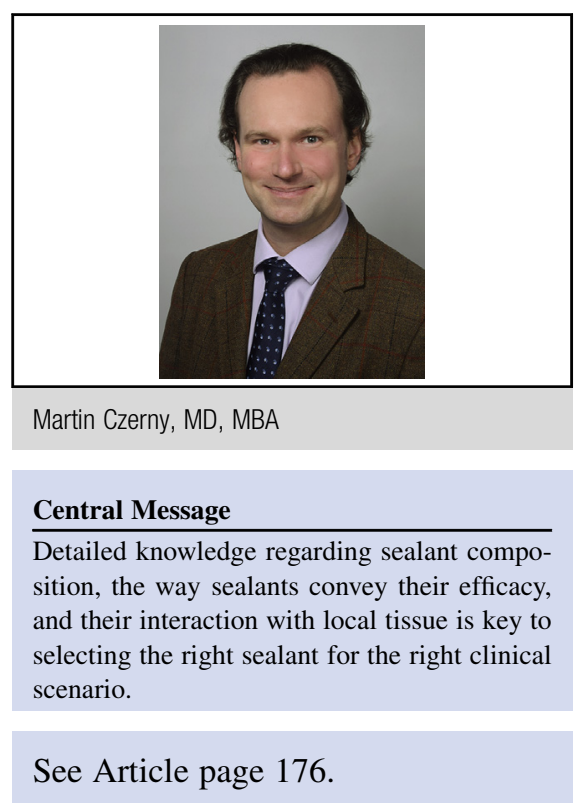

Summarizing, this study of Murdock and colleagues ${ }^{4}$ should be interpreted as a plea to the surgical community to pay attention to detail with regard to the sealants used in daily clinical practice, to be informed on their modes of action, and to anticipate interaction with local tissue beyond the acute effect of enhancing hemostasis.

\section{References}

1. Edmunds LH Jr, Colman RW. Bleeding that won't stop. Ann Thorac Surg. 2008; $85: 1153-4$

2. Task Force on Patient Blood Management for Adult Cardiac Surgery of the European Association for Cardio-Thoracic Surgery (EACTS) and the European Association of Cardiothoracic Anaesthesiology (EACTA), Boer C, Meesters MI, Milojevic M, Benedetto U, Bolliger D, von Heymann C, et al. 2017 EACTS/EACTA guidelines on patient blood management for adult cardiac surgery. J Cardiothorac Vasc Anesth. 2018;32:88-120.

3. Czerny M, Verrel F, Weber H, Müller N, Kircheis L, Lang W, et al Collagen patch coated with fibrin glue components. Treatment of suture hole bleedings in vascular reconstruction. J Cardiovasc Surg (Torino). 2000;41:553-7

4. Murdock MH, Chang JT, Luketich SK, Pedersen D, Hussey GS, D'Amore A, et al. Cytocompatibility and mechanical properties of surgical sealants for cardiovascular applications. J Thorac Cardiovasc Surg. 2019;157:176-83. 